\title{
Criticism Against Feminist's Thinking About Husband's and Wife's Rights and Obligations
}

\author{
Faisal $^{1}$, Moh. Mukri² ${ }^{2}$ Asriani $^{3}$
}

\begin{abstract}
Criticism Against Feminist's Thinking About Husband's and Wife's Rights and Obligations. Marriage is a legal place to foster a peaceful, harmonious and loving household (Sakinah mawaddah wa rahmah). In marriage, the fulfillment of the rights and obligations of husband and wife is the main means for achieving domestic happiness. In the Islamic perspective, the husband is the head of the household and the wife is the housewife. However, in modern times, along with the emergence of feminists, the concept of the rights and obligations of husband/wife are thus re-interpreted and reconstructed on the grounds that many wives are no longer serving as housewives but also help husbands in earning a living. As a result, the aspect of equality is more prioritized than the concept of mu'asyarah bil ma'rüf (harmonious relationship). This article examines the views of Muslim feminists about the role of husband/wife in a household, while comparing them with concepts that exist in Islamic teachings. In conclusion, the Islamic concept of the rights and obligations of wife and husband, if it is carried out consistently, will actually bring more benefit and permanence in the household than the feminist's which is only based on the equality argument.
\end{abstract}

Keywords: rights and obligations of husband and wife in Islam, criticism against feminist thought, marriage.

\begin{abstract}
Abstrak: Kritik terbadap Pemikiran Feminis Tentang Hak dan Kewajiban Suami Isteri. Perkawinan merupakan wadah yang legal untuk membina rumah tangga yang sakinah, mawaddah wa rahmah. Di dalam perkawinan, terpenuhinya hak dan kewajiban suami isteri merupakan sarana utama untuk tercapainya kebahagiaan rumah tangga. Dalam perspektif Islam, suami adalah kepala rumah tangga dan isteri adalah ibu rumah tangga. Konsep ini lebih ideal dibandingkan dengan konsep budaya atau agama-agama lain yang ada sebelum datangnya Islam. Namun, di masa moderen, bersamaan dengan munculnya kaum feminis, konsep tentang hak dan kewajiban suami/isteri yang demikian itu ditafsirkan ulang dan direkonstruksi dengan alasan para isteri banyak yang tidak lagi bertugas sebagai ibu rumah tangga melainkan turut membantu suami dalam mencari nafkah. Akibatnya, aspek kesetaraan lebih dikedepankan dibanding konsep mu'äsyarah bil márüf. Artikel ini mengkritisi pandangan kaum feminis Muslim tentang peran suami/isteri dalam suatu rumah tangga, sambil membandingkannya dengan konsep yang ada dalam ajaran Islam. Kesimpulan yang diperoleh menunjukkan bahwa konsep Islam tentang hak dan kewajiban suami isteri jika dilaksanakan secara konsekuen justeru akan mendatangkan kemaslahatan, keharmonisan, kedamaian dan kelanggengan dalam rumah tangga dibanding dengan konsep yang ditawarkan oleh kaum feminis muslim yang hanya mendasarkan pada pertimbangan kesetaraan semata.
\end{abstract}

Kata Kunci: hak dan kewajiban suami isteri dalam Islam, kritik terhadap pemikiran feminis, perkawinan. 


\section{Introduction}

Marriage in the perspective of Islam does not only mean a bond between a man and a woman that aims to form a household but also has a religious value. ${ }^{1}$ Marriage is a legal vehicle, which justifies sexual relations between men and women in the mitsäqan ghalidlan (a very strong bond). As a result of marriage will arise the rights and obligations of husband and wife as well as the division of tasks, where, according to the Islamic concept, the husband act as the head of the household and the wife as the housewife. ${ }^{2}$

Among the responsibility of the husband as the head of the household is that he is responsible for the livelihood of his wife and children, while the wife is responsible for household affairs, and may help her husband. ${ }^{3}$ However, the latest social phenomenon developing in modern society shows that many women try to help their husbands in making a living outside the home, which is actually the husband's duties and responsibilities. ${ }^{4}$ Based on this phenomenon, Muslim feminists try to reinterpret the concept of the rights and obligations of the wife to open up opportunities for the wife to be able to work outside the home. Consequently, with the shift in roles, there must also be a shift about rights and obligations in the household.

In Islam, marriage is a legal contract/bond (mitsāqan ghalìdhan) aimed at achieving harmony and prosperity in the household. The consequence of the contract is the arising of the rights and obligations of husband and wife. The Qur'an in a very wise way states that marital relations must be built on the principle of mu'asyarah bi al-ma'rüf (good relationship). A good husband is a husband who can please, care for and protect his

${ }^{1}$ Mahmudin; Hermanto Bunyamin, Hukum Perkawinan Islam (Bandung: Pustaka Setia, 2017), p. 12, <//library.unej.ac.id/index.php?p=show_detail\&id=212396>.

2 Agus Hermanto,'Rekonstruksi Konsep Hak dan Kewajiban Suami Isteri dalam PerundangUndangan Perkawinan Indonesia', Justicia Islamica Jurnal Kajian Hukum dan Sosial, 15.1 (2018), 49-86 <https://doi.org/10.21154/justicia.v15i1.1455>.

${ }^{3}$ Nova Anissa and Agustin Handayani,'Hubungan Antara Konsep Diri dan Kematangan Emosi dengan Penyesuaian Diri Istri yang Tinggal Bersama Keluarga Suami', Jurnal Psikologi: PITUTUR, 1.1 (2012), 53-64.

${ }^{4}$ Indah Indah,'Peran-Peran Perempuan dalam Masyarakat', Academica, 5.2 (2014) <http:// jurnal.untad. ac.id/jurnal/index.php/academica/article/view/2247> [accessed 20 October 2019]. 
wife; Similarly, a good wife is a wife who is able to please and help her husband. ${ }^{5}$ The concepts of justice and mu'asyarah bi al-ma'rüf, according to Islam, must be prioritized for the formation of a sakinah mawaddah wa rahmah family (a peaceful, harmonious and loving family). Normatively, the Qur'an characterizes the concept of equality between men and women on two things; First, in a general sense, equality means acceptance of the dignity of both sexes in the same size. Second, that men and women have equal rights in the social, economic and political fields.

This topic has previously been discussed by a number of authors, including: Tri Lisiani Prihatinah, in her article entitled Persepsi Pegiat Jender Terhadap Konsep Pasal 31 Ayat (3) Undang-Undang Perkawinan Tentang Status Kepala Keluarga (Perception of Gender Activists toward the Article 31 Paragraph (3) Of Indonesian Marriage Law Regarding the Status of the Head of Family and Agus Hermanto with the title Rekonstruksi Konsep Hak dan Kewajiban Suami Isteri dalam Perundang-undangan Perkawinan Indonesia (Reconstruction of the Concept of Rights and Obligations of a Husband and Wife in Indonesian Marriage Law). Both of these works have the same conclusion that the concept of gender is acceptable. According to them, both the classical'ulama perspective and the Muslim feminist paradigm have very strong arguments to be considered for the benefit of a married couple.

This study has a different perspective from what has been written by the two authors above. This research will provide a critique against the views of Muslim feminists as pioneers of the equality movement which sometimes transcends the limits of syara' (Islamic Law). The main focus is to answer the question whether or not the concept of equality is absolutely needed in an effort to create a sakinah, mawaddah wa rahmah (peaceful, harmonious and prosperous) in household.

\section{The Concept of Maslahat in Islam}

The term maslahat is derived from Arabic word shalaha which means good (antonym of bad); maslahat means: goodness, usefulness,

${ }^{5}$ Agus Hermanto,'Islam, Perbedaan dan Kesetaraan Gender', Nizham Journal of Islamic Studies, 5.1 (2017), 31-49 (pp. 31-49). 
appropriateness, worthiness, harmony, and propriety, as opposed to the word al-mafsadah which means damage. ${ }^{6}$ Thus, the word maslahat is used to indicate someone or something that is good. ${ }^{7}$ Similarly, the Indonesian Dictionary distinguishes between the words "maslahat" and "kemaslahatan". The Dictionary puts the word "maslahat" as the basic word, while the word "kemaslahatan" as an invented noun that comes from the word "maslahat" which gets the prefix "ke" and the suffix "an". The word "maslahat", according to the dictionary, is interpreted as "something that brings goodness, principles and uses" while the word "kemaslahatan" means : usefulness, goodness, benefit, importance. ${ }^{8}$

In the ushül fiqh, the concepts of good and bad in terms of maslahat have certain criteria:

1. The basis of maslahat is religious guidance, not solely based on human reason which is very limited, easily provoked by environmental influences and passions.

2. Good and bad in the study of maslahat are not only limited to worldly issues but also ukhräwi (hereafter) affairs.

3. Maslahat in Syara' perspective is not only aimed at solely by Jasadiyah (physical) pleasure, but also in terms of rühäniyah (spiritual) pleasure. ${ }^{9}$

In Islamic Law, the term Maslahat is often called maslahat mursalah, or istisläh, that is a legal problem that is not mentioned by the shariah and there are no arguments telling to work or leave it, if it is done, however, it will bring great good/benefit. Mashlahat is also called absolute mashlahat because there is no proposition that recognizes its validity or invalidation. So the formation of law using the concept mashlahat solely to realize the goodness of humans, in a sense, to bring benefits

${ }^{6}$ Asmawi Asmawi,'Konseptualisasi Teori Maslahah', SALAM: Jurnal Sosial dan Budaya Syar-i, 1.2 (2014), p. 314 <https://doi.org/10.15408/sjsbs.v1i2.1548>; Muhammad Roy Purwanto,'Kritik Terhadap Konsep Mashlahah Najm Ad-Dîn At-Tûfi', Madania: Jurnal Kajian Keislaman, 19.1 (2015), p. 29 <https://doi.org/10.29300/madania.v19i1.23>.

7 Kutbuddin Aibak, Metodologi Pembaharuan Hukum Islam (Yogyakarta: Pustaka Pelajar, 2008), p. 187.

${ }^{8}$ Imron Rosyadi,'Pemikiran Asy-Syâtibî Tentang Maslahah Mursalah', Profetika Jurnal Studi Islam, 14.1 (2016), 78-89-89 (P. 82) <Https://Doi.Org/10.23917/Profetika.V14i1.2009>.

${ }^{9}$ Amir Syarifuddin, Usul Fikih, 2 (Jakarta: Logos Wacana Ilmu, 1999), p. 91. 
and reject harm to humans. ${ }^{10}$ According to al-Syātibī what is meant by al-maslahat in the sense of shari'a is to take advantage and reject harm which is not only based on common sense alone. This is also in tune with the concept of sad źarīàt, which was initiated by al-Syātibī, that the true purpose of law is jalb al-masālih wa daf'u al-mafäsid (ie taking benefit and rejecting hardship).

When there is an event or events that need to be determined by law but none of the texts (al-Qurân and al-Sunnah) can be used as a basis, then the mujtahid may use Masālibul Mursalah as the basis of his ijtihäd. If the case provides benefits for humans, the law may be applied; But if it does not bring benefits or instead bring harm then the law must not be applied. This principle was agreed upon by the majority of Muslim jurists, including Imam Mālik, al-Ghazāli and Imam al-Qarafi al-Thufī.

Imam Mālik, as the first person to use the theory of maslahat (benefit), argues that to be used as a source of law the maslahat must meet several criteria, namely the conformity with the general objectives of the Shari'a and does not conflict with the text. ${ }^{11}$ In line with that, al-Ghazāli asserted that maslahat can be used as legal proposition if: first, the maslahat has become a strong $d z a n$ (after conducting research based on several considerations, mujtahid has been able to draw the conclusion that the problem is truly a maslahat in line with the type of action; Secondly, the maslahat belongs to the type of maslahat left by the shari'ah (the benefit/maslahat does not conflict with texts, or ijmā.) ${ }^{12}$ Imam al-Qarafi al-Thūfī, in his book Masālihul Mursalah, limits the use of benefits to matters in the field of mu'amalah (human relation). While in matters of worship the law is in the hands of Allah (al-Qurān and Hadith), because humans will not be able to fully know the wisdom behind the worship. ${ }^{13}$

${ }^{10}$ Moh. Mukri, Paradigma Maslahat dalam Pemikiran al-Ghazali (Yogyakarta: Nawesea Press, 2011), p. 181.

${ }^{11}$ Abu Ishaq al-Syatibi, Al-I'tisām, II (Riyadh: al-Haditsah, t.t), p. 117.

${ }^{12}$ Moh. Mukri, p. 95.

${ }^{13}$ Amir Syarifuddin, Usul Fikih, 2 (Jakarta: Logos Wacana Ilmu, 1999). 
Muslim scholars use maslahat as one of the arguments in deciding a law based on the following facts:

1. Problems faced by humans always grow and develop, as well as the interests and needs of his life. Many things or problems that did not occur during the time of the Prophet, then arose and occurred in the period afterwards. So, if there is no argument that can solve such things, human life will be narrow. The evidence in question is the proposition which can determine which is benefit and which is not. If the proposition exists, then the benefit of humans at every time, situation and place can be realized.

2. The Prophet's Companions and those who came afterwards had applied the benefit principle, so that they could immediately establish the law in accordance with the benefit of the Muslims at that time. For example: Khalīfah Abū Bakar collected the Koran. Khalifah Umar stipulated divorce that was pronounced three times at the same time the status was the same as divorce three, whereas at the time of the Prophet, it was only counted one. The Caliph Uthman ordered the writing of the Koran in one Manuscript, and other policies that brought good for the Muslims, etc. ${ }^{14}$

Imam al-Ghazāli itemized the concept of maslahat based on three aspects, namely:

1. Based on normative validity or availability of supporting text. Here al-Ghazāli divides maslahat into three types, namely; a) Maslahat that is supported by its validity in sharia and can be made as'illat (argument) in qiyass (analogy. b) Maslahat that is supported by the shariah of its cancellation. c) Maslahat which does not have the support of shar'i in terms of validity or invalidity. ${ }^{15}$ For the three types of maslahat, al-Ghazāli named them with the term: maslahat muitabarah, maslahat mulghah dan maslahat mursalah. ${ }^{16}$ Maslahat Mu'tabarah is

${ }^{14}$ Amir Syarifuddin, p. 181.

${ }_{15}$ Wahbah Zuhaili, Usūl al-Fiqh al-Islāmī, 2 (Beirut: Dar al-Fikr, 1987), p. 769.

${ }^{16}$ Amir Mu'allim and Yusdani, Konfigurasi Pemikiran Hukum Islam (Yogyakarta: UII Press, 2001), p. 68; also see Hamzah K,'Revitalisasi Teori Maslahat Mulghâh Al-Thûfí dan Relevansinya dalam Pembentukan Perundang-Undangan di Indonesia', AHKAM : Jurnal Ilmu Syariah, 15.1 
maslahat expressed directly both in the Qur'an and the Hadith of the Prophet. Maslahat mulghah, is a maslahah that contradicts the provisions contained in the Qur'an and al-Hadith. Whereas maslahat mursalah is the benefit which is not stipulated in the Qur'an and the Hadith but also does not conflict with the two sources. ${ }^{17}$

2. Based on the functional validity of the benefit itself.

Al-Ghazāli provides several conditions for the enactment of the Maslahat (benefit) namely; a) The benefit is very essential and primary (dharüriyah), b) The benefit is very clear and firm (qat'iyyah), c) The benefit is universal (kuliyyah), d) The benefit is based on the universal proposition of the whole qarinah (mu'tabarah). ${ }^{18}$

3. Based on its position.

Al-Ghazāli asserted that the position of maslahat in the legal system is only as a perfection (takmilan and tatimah). ${ }^{19}$

The application of the maslahah/istisläh method as a basis for establishing law among the jurists is generally motivated by the following interests:

1. Jalb mashälih, (seeking goodness) that is important matters needed by the community to build human life on a solid foundation.

2. Dar'u mafäshid, (rejecting the bad), that is, matters which make human beings both individual and group, both material and moral.

3. Syadz dzariah, (closing the road) that is closing the road that can waste the shariah command, or can lead to the prohibition of sharia even if unintentionally.

4. Taghayyur al-azmān, (changing times) that is the human condition, morals, and general demands that are different from the previous period. ${ }^{20}$

(2019), p. 27 <https://doi.org/10.15408/ajis.v15i1.2845>.

${ }^{17}$ Amir Mu’allim and Yusdani, pp. 68-69.

${ }^{18}$ Hamka Haq dan al-Syātibi, Aspek Teologis Konsep Maslahah dalam Kitab al-Muwafaqat (Jakarta: Erlangga, 2007), p. 251.

${ }^{19}$ Wahbah Zuhaili, pp. 170-71.

${ }^{20}$ Mustafa Ahmad al-Zarqa', Hukum Islam dan Perubahan Sosial; Studi Komperatif Delapan Madzhab, Transl. Ade Dede Rahayu (Jakarta: Riora Cipta, 2000), p. 72. 
Whereas the legality of the maslahah/benefits in the study of jurisprudence also very much depends on a number of criteria including; 1) The benefit must be definite, not just a figment or assumption that it does manifest a benefit, or prevent harm. 2) The benefit is not only a personal interest, or a small part of the community, but is general in nature. 3) The results of the reasoning maslahat does not lead to neglect of a principle set by the shari'ah texts. ${ }^{21}$

By referring to the above principles, the opportunity to use the maslahat method to address contemporary problems is wide open, so that Islam can not only become the religion of rahmatan li al-älamin, but also be a religion that is flexible, dynamic and just. ${ }^{22}$

According to al-Ghazali, there are several things that must be observed in using the concept of benefits, namely:

1. Maslahat is to seek benefits and avoid danger. ${ }^{23}$ al-Ghazāli defines benefits not as something that is the goal of every person, but the benefits he means are benefits in the realm of the world and the hereafter.

2. Maslahat is not only limited in language and'urf, but more than that, namely maintaining the purpose of maqūshid al-syarīah, that is protecting usūl al-khamsah, (hifdu al-dìn, hifdzu al-nafs, hifdzu al-'aql, hifdzu al-nasl, dan hifdzu al-mäl). ${ }^{24}$

3. Strictly speaking, al-Ghazāli defines maslahat as what is meant by Allah, not in the eyes of humans. So anyone who wants to achieve the benefits, he must not come out of the teachings of Islamic sharia. Because the benefits that humans seek are not necessarily the same benefits that are desired by God.

${ }^{21}$ Anang Haris Imawan, 'Refleksi Pemikiran Hukum Islam: Upaya-Upaya Menangkap Simbol Keagamaan', in Anang Haris Himawan, Epistimologi Syara' Mencari Format Baru Fikih Indonesia, I (Jakarta: Pustaka Pelajar, 2000), p. 84.

${ }^{22}$ Nu’man al-Jughaini, Turūq al-Kasyfían Maquashid al-Syarīah (Yordania: Dār al-Nafảis, 2000), p. 72.

${ }^{23}$ Muksana Pasaribu,'Maslahat dan Perkembangannya Sebagai Dasar Penetapan Hukum Islam', JUSTITIA : Jurnal Ilmu Hukum dan Humaniora, 1.04 (2016), P. 352 <Https://Doi. Org/10.31604/Justitia.V1i04.\%P>.

${ }^{24}$ Muhammad Ali Rusdi,'Maslahat Sebagai Metode Ijtihad dan Tujuan Utama Hukum Islam', DIKTUM: Jurnal Syariah dan Hukum, 15.2 (2017), 151-68 (p. 168) <https://doi. org/10.35905/diktum.v15i2. 432>. 
4. Maslahat according to al-Ghazāli is a synonym of al-mànā al-munāsib, therefore under certain conditions it is often also called qiyass (analogy). Al-Ghazāli also gave several signs that must be observed in applying the concept of benefits in a case, namely:

1. The concept of maslahat is not only limited to understanding language and bahasa urf only; It also includes maintaining the goal of the maquashid al-sharìah, which is to safeguard the five basic elements (usül al-khamsah), namely: guarding the religion (bifdu aldin), guarding the soul (bifdzu al-nafs), guarding the mind (bifdzu al-'aql), guarding offspring (bifdzu al-nasl), and guarding property (bifdzu al-māl). ${ }^{25}$

2. Maslahat is what is meant by God, not according to human view. Therefore, everyone who wants to achieve maslahat/benefit must follow the teachings of Islamic Sharia. Because the benefit that humans want is not necessarily the same as what God wants.

3. Maslahat is seeking benefits and avoiding danger. ${ }^{26}$ The benefits here are not limited to worldly benefits, as is the goal of everyone, but that covers both the fields of the world and the hereafter.

4. Maslahat is a synonym of al-ma'nā al-munāsib, which in certain conditions is called qiyās.

Like the previous fuqaha, Najmuddin al-Tüfi also accepted maslahat as the basis for establishing the law. He departed from the concept of maquashid al-syarīah which asserts that Islamic law is prescribed to realize universal humanitarian benefit. Al-Tûfi based his opinion on the Hadith of the Prophet: "Neither can make harm nor be made harm by other people" (Hadith al-Hākim, al-Baihaqi, al-Daruqutni, Ibn Mājah and Ahmad ibn Hanbal). This hadith là dzarara wa là dzirār, according to al-Tūfi, provides a general principle regarding the prohibition to do harmful actions. The

${ }^{25}$ Muhammad Ali Rusdi,'Maslahat Sebagai Metode Ijtihad dan Tujuan Utama Hukum Islam', DIKTUM: Jurnal Syariah dan Hukum, 15.2 (2017), 151-68 (p. 168) <https://doi. org/10.35905/diktum.v15i2.432>.

${ }^{26}$ Muksana Pasaribu,'Maslahat dan Perkembangannya Sebagai Dasar Penetapan Hukum Islam', JUSTITIA : Jurnal Ilmu Hukum dan Humaniora, 1.04 (2016), P. 352 <Https://Doi. Org/10.31604/Justitia.V1i04.\%P>. 
legal content of this hadith, according to him, is "Unauthorized actions that cause harm (to others) except for compelling reasons (such as punishment for lawbreakers justified by sharia)". The prohibition on doing acts that harm others is also contained in the word of God, among others: God wants ease for you, and does not want trouble for you (al-Baqarah, [2]: 185). "Allah wants to lighten your burden" (al-Nisa' [4]: 28) "He (Allah) does not determine your difficulties in religion" (al-Maidah, [5]: 6).

The concept of benefits explained by al-Tûfi and al-Ghazāli, in principle, has the same goal, namely the benefit of humans and avoid harm. It's just that, in contrast to al-Ghazāli who prefers texts rather than ratios, Al-Tūfi develops more reasoning and logic in determining benefit, because human reason basically can distinguish between the maslahat and mudharat. Al-Tüfi considers that reason has a higher value in the evaluation of the text, and this is possible then that al-Tüfi is considered excessive in understanding the concept of maslahat. Although al-Tüfi provides a different concept compared to al-Ghazāli, one thing must be kept in mind that al-Tüfi still limits the concept of maslahat only to the scope of mu'amalāt and'ädat and not to the area of worship or cases that already have an argument (muqaddarah). So, maslahat can only be applied to cases where texts (the Qur'an and al-Sunnah) as sources of Islamic law have not provided a legal basis.

Al-Tūfi divides Islamic law into two categories, namely Islamic law which belongs to the purpose of worship whose intentions and meanings have been determined by the syarriah so that the human mind is unable to reason in detail; and what enters into the category of mu'amalāt whose meaning and purpose can be reached by reason. In the category of mu'amalāt, benefit is a guide both when there is text or ijmā or even without the two propositions intended and its purpose can be used by reason. In the category of mu'àmalāt, maslahat is a guide both when there is text or ijma $\bar{a}$ 'or even without the two propositions. $^{27}$

${ }^{27}$ Yusuf al-Qaradhawi, Dirasah Fi Fiqh Maqashid al-Syariah, Transl. Arif Munandar Riswanto (Jakarta: Pustaka al-Kautsar, 2007), p. 217. 
Operationally, al-Tūfi's maslahat especially in the realm of mu'ämalāt is built on four principles, namely:

1. Istiqlāl al-'uqūl bi idrāk al-masālìh wa al-mafäsid (reason can only know about benefit and interpretation).

2. Al-maslahah dalīlun syar'iyyun mustaqillun'an al-nusüsh (maslahat is an independent proposition of the text).

3. Majāl al-'amal bi al-maslahat humā al-muāmalat wa al-'àdat dūna al-ibädat wa al-muqaddarah (the realm of the practice of maslaha is in the field of muamalah and'ädat not in worship and muqaddarah).

4. Al-maslahah aqw adillat al-syar'i (maslahat is the most powerful proposition of Islamic law). ${ }^{28}$

In the field of mu'āmalāt, al-Tūfi places maslahat as top priority over standard sources of law (al-Qur'an, Sunnah/Prophetic traditions, and ijm $\vec{a})$. This caused him to be often accused of being a controversial figure in the Hanbali school of thought because it was considered excessive in assessing the maslahat/benefits. ${ }^{29}$

According to al-Tūfi, the most powerful sources of traditional law are religious texts (al-Qur'an and Sunnah or Prophetic traditions) and consensus of jurists (ijmá '). As long as these two sources are in line with the protection of human's maslahat/benefits, everything is going well and there is nothing to be questioned. However, if they are not in line, then the protection of maslahat takes priority over the two sources. Giving priority to the protection of benefit, said al-Tüfi is not intended to stop or deny the validity of the two sources, but merely to explain their function proportionally.

Al-Tũfi also rejected the division of benefits as carried out by a number of fuqaha. In his opinion, such a division is not very relevant, considering the main purpose of the sharia is benefit. Therefore, all forms of benefit, whether supported or not supported by the sacred text, must be achieved without having to break down into categories. ${ }^{30}$ Protection of human's

${ }^{28}$ Saifuddin Zahri, pp. 125-27.

${ }^{29}$ Mustafa Ahmad Zarqa', Al-Istisläh Wa al-Masǟil al-Mursalah Fì al-Syarīah al-Islämiyah Wa Usül Fikih, Transl. Ade Dedi Rohayana (Jakarta: Reora Cipta, 2000), p. 81.

${ }^{30}$ Saifuddin Zahri, Usül Fiqh: Akal Sebagai Sumber Hukum Islam, II (Yogyakarta: Pustaka Pelajar, 2011), p. 117. 
benefit, according to al-Tüfi, is the highest and most powerful source or principle of law as well as the main purpose and axis of sharia intent.

In contrast to religious texts, which according to al-Tüfi, are different from and contradict each other, human benefit is something that is real, substantial, strong, and more convincing, because legal or social benefits can be known by humans through their radiant intelligence, reason or life experience that has been bestowed by God. This is different from religious texts, which are sometimes mutawätir (convincing) and sometimes ahad (less convincing); sometimes their literal statements and rules of law are clear or qath'i, and sometimes mubtamall dhanni (unclear). If the text is mutawätir and qathi then it is convincing or definitive. But if it is mubtamal or dhanni in terms of generality or infinite significance, then the absolute certainty of the text can be denied or doubted. Similarly, if the text of the hadith is ahad or not mutawatir, then it is said to be inconclusive, regardless of whether it is clear in its statement or not because the authenticity of the transmission is doubtful. Consequently, in the view of al-Tüfi, the highest judge or the highest authority of the legal and social benefit of human beings is the human intellect or intelligence itself.

Al-Tüfi also prioritizes the principle of human benefit over the ijmä. He rejected the claims of legal experts stating that there was no possibility of wrong with $i j m \bar{a}^{-}$. This claim is based mainly on the Prophet's hadith: "My people will not agree on error". If ijmâ is indisputable evidence, al-Tüfi emphasized, then it might be caused by persons who agreed unanimously, or because of the support of" religious texts "which were based on the Prophet. The hadith "My people will not agree to error", according to alThūfi, does not at all mean that Muslims have agreed or that their ijmā cannot be wrong or that someone must follow it. He reasoned that:

1. Many Muslims reject the content or authenticity of this hadith and also ijmā itself, for example the Khawarij, the Shīah, the Zahiri and people such as al-Nazzam, the Mu'tazilah figures;

2. The claim that the ijmā of Muslim community as a whole has been accepted is a claim made to legitimize ijma, and this is a wrong argument method because it contains an attempt to prove something with itself. 
3. Even if the hadith is a mutawatir, there is no obligation for everyone to follow it. Because, it is possible (assuming the hadith is authentic) the intention of the Prophet in that hadith is that my people will not agree on matters leading to kufr. Therefore, he concluded, this hadith is not a strong evidence or argument for the obligation to follow ijm $\vec{a}$, except concerning faith as opposed to kufr.

4. There is a conflict between the intentions of the above hadith and another hadith which is also propped up against the Prophet, $M y$ people will be divided into 73 groups, all in hell except one. Al-Tüfi questioned whether what was meant by the people who would not agree on the heresy was all groups of 73 groups or only one group. If what is meant is the whole group then it is invalid, for two reasons (1) some of them do not support ijm $\vec{a}$, as already stated, and as such, it is not valid to consider $i j m \vec{a}$ from those who refuse $i j m \vec{a}$. (2), among Muslim groups, there are some groups which are considered unbelievers because of their heresy, and as such, infidels are not considered included in ijm $\vec{a}$.

Al-Tüfi's views on maslahat differed broadly from those of the ulama', including al-Ghazāli. If the ulama besides al-Tüfi interpret the existence of maslahat which is still in syara' circle', al-Thūfi goes further and tends to base maslahat on the superiority of reason, because human reason, according to al-Tūfi is more objective in positioning the benefit criteria compared to the contradiction between syar'i texts. That is why the validity of maslahat must be prioritized above other propositions even to the texts of sharia. ${ }^{31}$

Al-Tüf's argument is based on the hadith of the prophet which reads là dharara wa là dhirār. According to al-Tūfi, this hadith is a very basic principle of sharia as the benefit is essentially to prevent the difficulties and is needed to make it easy for people who are facing difficulties. Consequently, if there are texts and which must adjust to the benefit in a particular case, then it must be done, but on the contrary, if between texts and $i j m \vec{a}$. contradicts the benefit, the two propositions must submit

${ }^{31}$ Muhammad Muslehuddin, Philosophy of Islamic Law and The Orientalist: A Comperative Studi of Islamic Legal System, transl. Yudian Wahyudi Asmin (Yogyakarta: Tiara Wacana, t.t), p. 133. 
to the benefit. Al-Tüfi argued that the texts (al-Qur'an and al-Sunnah) were made by al-Shari' for the benefit of humans and not vice versa. If there are arguments that consider the text irrelevant, then the problem must be returned to the benefit.

The priotization of maslahat from texts and ijm $\vec{a}$ for al-Tûfi is based on several arguments:

1. Nash allows a lot of disagreement to cause differences of opinion, while maintaining substantial benefit is something that is essential, so that the priority of the benefit is the cause of the agreement desired by the Shariah.

2. Factually, there are some texts that were rejected by the Prophet's companions under maslahat consideration. One of which is the hadith of the Prophet which means "Whoever utters the phrase la ilàha illallah then enters heaven". Umar forbade the spread of this hadith because based on considerations of benefit, if only this lafadz was distributed, then there would be laziness to worship only by relying only on the hadith.

3. The validity of Ijmā is still disputed, while the validity of maslahat has been agreed upon by the scholars', so that prioritizing something that was agreed is more important than something that is still disputed. ${ }^{32}$

Apart from Al-Thūfîs controversial view of applying the concept of Masālibul Mursalah as a basis for establishing law, one thing must be kept in mind that all of this applies only to the fields of mu'àmalah, 'ádat and the like, whereas in the area of worship only al-Syāri (God) who absolutely set it. Al-Thūfî asserted that in matters of worship only Allah can determine the law, because humans are not able to know the full wisdom behind the worship. That is why Muslims must worship in accordance with the provisions contained in the Qur'an and the Hadith. ${ }^{33}$

${ }^{32}$ Ahmad Munif Suratmaputra, Filsafat Hukum Islam (Jakarta: Pustaka Pirdaus, 2001), p. 91.

${ }^{33}$ Amir Syarifuddin, Usul Fikih, 2 (Jakarta: Logos Wacana Ilmu, 1999). 


\section{Rights and Obligations of Husband and Wife in Muslim Feminist Perspectives}

Muslim feminists consider that in the current social reality there are hardly any women who can be restricted in their domestic space, because they are also indirectly required to keep abreast of the times with all their changes. Women accept work to maintain the cleanliness and tidiness of the household, starting from cooking, washing, ironing and caring for children. Besides having to tidy up household affairs, they must also help work in the public sector to earn extra income for their families. For middle class families, this burden will be carried out by domestic servants. However, even this housemaid, who is generally also a woman, the workload of the household multiplies; As a result of all domestic work become her responsibility, the burden of women's work becomes heavier, and the time and energy spent by women becomes more and heavier than men. It is women who are the last to go to bed at night and get up early in the morning. So it can be said that the wife's working hours from before the husband woke up to the husband's eyes closed. ${ }^{34}$

This phenomenon has prompted a number of feminist activists to study and propose to restructure classical religious thoughts, especially those in interpretation, to get adjusted to the current socio-cultural situation. Classical interpretations, which are a reflection of the past socio-cultural conditions, are to be reconstructed because they are no longer in accordance with the position of Islam as the religion of shälibun fi kulli zamān wa makān (a religion that can be applied in any time and place). ${ }^{35}$

Among a number of feminist activists who strive to fight for the idea of gender equality, the names of Musdah Mulia, Ratna Bantara Munti, Nasaruddin Umar, Mansour Faqih, Syafiq Hasyim, Husein Muhammad, Masdar Farid Mas'udi, and others.

Musdah Mulia after studying Surah al-Nisa verse 32 in terms of language, finding the words rijäl and al-nisäare not the only terms used

${ }^{34}$ Alawy Rachman, Alawy Rachman, Gelas Kaca dan Kayu Bakar, Pengalaman Perempuan dalam Pelaksanaan Hak-Hak Keluarga Berencana (Yogyakarta: Pustaka Pelajar, 1998), p. 7.

${ }^{35}$ A. Qodri Azizy, Pemikiran Islam Kontemporer di Indonesia (Yogyakarta: Pustaka Pelajar, 2005), pp. 107-9. 
in the Qur'an to express the meanings of men and women. There are two other words for male meanings namely rajul (singular form) and al-rijäl (plural) or al-zakar (singular) and al-zakar (plural). By using contextual understanding, Musdah Mulia concluded that in reality not all men are able to play a role beyond women. In many cases many wives are able to play a role in the public sector better while simultaneously holding the role of leader in the household. Therefore, it cannot be forced that the husband must be the head of the household and the wife as the housewife.

Ratna Bantara Munti views that basically the concept of an ideal husband and wife relationship according to Islam is the concept of equal partnership or relations, as mentioned in al-Baqarah, [2]: 187. The moral ideal content of this verse is in principle the position of men and women are equal, and their social position is the same. This is in line with the principle of equality as referred to in al-Nisä, [4]: 124. It is only in the field of sex such a distinction occurs and not in the area of gender.

According to Nasharuddin the occurrence of injustice between women and men is caused by a number of factors, including: 1) The unclear difference between the concepts of sex and gender in defining the roles of men and women. 2) Influence of widespread Isra'iliyyat stories in the Middle East region. 3) The method of interpretation that so far refers to a textual approach rather than contextual. 4) Readers of the verses of the Qur'an that are not neutral in judging or influenced by other perspectives in reading verses related to gender. So it seems as if it is suggested that the Koran favors men and supports a patriarchal system which is considered by feminists to be detrimental to women. In other words, gender bias arises because of how to read gender verses that tend to be partial. ${ }^{36}$

Nasarudin considered that leadership in the family was something given to her husband. The main reason why husbands themselves are family leaders is because of the fadl (superiority) they have over women, which is seen as something absolute. In addition, the responsibility for the livelihood

${ }^{36}$ Nasaruddin Umar, dkk, Bias Jender dalam Pemahaman Islam (Yogyakarta: Gama Media, 2002), p. 21-22. 
which is imposed on the man for his wife and other family members is also the reason why the husband must hold power in the family. ${ }^{37}$

When talking about the concept of equality, Nasaruddin agreed that men and women should be seen as partners who are able to work together and help one another. Both husband and wife have the right to be the leader of the household. The wife has the right to become household leaders if the wife has a fadl (virtue) in public affairs. However, he also reminded that whoever becomes the head of the household should always prioritize the principle of sakinah, mawaddah wa rahmah to maintain the continuity of the household.

Mansour Fakih emphasized the attitude of how to instill and change people's lifestyles in order to develop a new culture that is bilateral. Habits and understanding as well as attitudes towards boys and girls must be pursued in such a way so that gender equality can be realized. ${ }^{38}$ Violence experienced by many women today is generally caused by a wrong gender view. This mistake resulted in the emergence of all forms of physical and non-physical violence, which prevailed at the household level, at the State level, even in religious interpretations. ${ }^{39}$

Similar to the above view, Syafiq Hasyim believes that equality is the main principle of justice. Justice, according to him, is to see the equal and balanced position of men and women without being based on natural differences. Syafiq emphasized the philosophical meaning of the man and woman as a balance before God except in the matter of piety. As for the rights and obligations in the household both are balanced and do not have to be differentiated except in the case of sex, namely sex differences. ${ }^{40}$

Husein Muhammad reviewed the concept of equality through a sociological and cultural perspective. He asserted that Islam was present for the first time in the midst of a very thick Arab patriarchal culture. They

${ }^{37}$ Nasaruddin Umar, dkk, Bias Jender dalam Pemahaman Islam, p. 86.

${ }^{38}$ Mansour Fakih, Analisis Gender \& Transformasi Sosial (Yogyakarta: Insist Press, 2016), p. 157.

39 Mansour Fakih, Analisis Gender \& Transformasi Sosial, p. 17.

${ }^{40}$ Syafiq Hasyim, Hal-Hal Yang Tak Terpikitkan Tentang Isu-Isu Perempuan dalam Islam (Bandung: Mizan, 2001), p. 263. 
greatly exalted men and maleness, and, on the contrary, underestimated the potential of women. Such culture influences and shapes awareness and assumptions that women are passive creatures, while men are destined to continue to be active. Such assumptions in turn greatly influence the form of religious appreciation that we have inherited to date. ${ }^{41}$

Husein also added that the position of women subordinated by men actually arose and was born from a community building or civilization controlled by men, which is popularly known as patriarchal civilization. Therefore, it will be a big mistake if you want to position women in such cultural settings into social settings and modern culture as it is today. Today's reality shows that the views on the greatness of men and the weaknesses of women from the intellectual and professional sides are being sued and torn down, even though the hegemonic hands of men are still trying (through awareness or not) to maintain their superiority. ${ }^{42}$

Therefore, according to Husein, justice and benefit must be the basis in making laws. The law can change if it does not contain social good. Patriarchal fiqh products dominate the entire domestic space, including marriage. Where women are the property of the husband, so the wife does not have sexual rights over her husband and also control over himself because his whole body belongs to the husband. As a result, women as closed wives and ashamed to express their desires for their husbands. Another thing that can be found in households where women do not have rights as leaders is that it is difficult for women to make decisions in the household, even for themselves. Eventually the wife becomes very dependent on her husband and her rights as a wife become neglected. ${ }^{43}$

Furthermore, Hussein Muhammad gave a response that if culture is the reality of the life of human society which includes traditions, patterns of everyday human behavior, law, thoughts and beliefs, then culture that appears in general still shows clearly its partiality in men. People call it patriarchal culture. In this culture, establishing the role of

${ }^{41}$ Mufidah, Isu-Isu Gender Kontemporer dalam Hukum Keluarga (Malang: UIN Maulana Malik Ibrahim, 2010) p. 143.

${ }^{42}$ Mufidah, Isu-Isu Gender Kontemporer dalam Hukum Keluarga, p. 22.

${ }^{43}$ Mufidah, Isu-Isu Gender Kontemporer dalam Hukum Keluarga, p. 15. 
men to do and determine anything, consciously or not, get justification. Instead women are in a subordinate position. He becomes a part of men and depends his life to men. Female autonomy is reduced. This situation is often proven to give birth to a process of marginalization, even exploitation and violence against women. This happens in all spaces, both domestic and public. ${ }^{44}$

This is a social fact in society, the awareness of men and women is quite weak. The biased assessment of women basically also starts with three basic assumptions about religious beliefs, namely; 1) The doctrinal assumptions that explicitly place women as a complement, 2) the dogma that women's ethical ethical talent is lower, 3) The materialistic view, ideology of the pre-Islamic Makkah community which views women in the production process. ${ }^{45}$

In contrast to the above concept, Masdar Farid Mas'udi views that the wife's right to earn a living and guarantees of welfare from her husband, is partly because normatively it has been mentioned in the passage (al-Qur'an and hadith), and partly because the wife has a role and responsibility that is quite large in household reproduction and management. It is very unfair if a woman or wife is also burdened with problems of living expenses (for food, shelter, clothing, health, etc.). The husband, therefore, should bear the responsibility. ${ }^{46}$

\section{Criticism of Feminist Views on the Position, Rights and Obligations of Husband and Wife}

The form and orientation of the issue of gender equality in a domestic relationship echoed by Muslim feminists is not clear; It is still unobvious whether it means to equalize position and role of a husband and a wife, or the shift of duties and responsibilities between the two, or an overhaul of the existing concept. In addition, their interpretation of the Qur'an and hadiths about the role of husband $\&$ wife in the

\footnotetext{
${ }^{44}$ Muhammad and Kodir, p. 183.

${ }^{45}$ Muhammad and Kodir, p. xiii.

${ }^{46}$ Masdar F. Mas'udi, Islam dan Hak-Hak Reproduksi Perempuan: Dialog Fiqih Pemberdayaan (Bandung: Mizan, 1997), p. 115.
} 
household is solely based on the consideration of ratios that depart from the general phenomena occuring in Western society. In fact, in order to obtain a comprehensive understanding of a domestic relationship it also requires emotional (love and affection) and spiritual considerations (practice of religious values) as the main pillars for wholeness, harmony, and survival of a household.

Furthermore, if the position and role of women are no longer in the domestic field, then, contextually and practically, all the responsibilities of a husband towards his wife, especially in the area of living, are no longer absolute. This may cause problems as basically the husband with his role as head of the household is obliged to meet all household needs both for his children and his wife. It is under this reason that Islam do not oblige the wife to carry the burden of the household; she is only responsible for managing household and finances, caring for children, and other domestic matters. Even if the wife works to earn a living outside, then it must be seen as an effort to help her husband to strengthen the household economy, not as a basis for reconstructing the position and role of the wife in the household.

Furthermore, marriage is also a form of construction of sad alzariah (closing of the path of badness) of previous shari'ah which has been passed down to the previous people. Then Islam came and offered the ideal concept of separating the role of the husband as the head of the household and the wife as the housewife. Unfortunately, in the modern era, especially in the post-industrial era, this concept is no longer carried out consistently by a handful of Muslims, because they view that the concept is no longer relevant and contradicts the concept of gender equality that continues to be echoed by feminist activism. The development of casuistic modern society is then used as'illat (basis of argument) by feminists to equalize the role of husband with the role of wife through their ijtihad. If the concept is used as a reference, it will only bring harm to the continuity and harmony of the family. In fact, the concept of the rights and obligations of husband and wife in Islam is actually more just, more dignified and more beneficial than the concept of equality in ensuring continuity, integrity and harmony in 
the household. The purpose of marriage in Islam is not only to fulfill biological and material needs, but, more than that, to fulfill the spiritual needs of humans to be able to live well in the world and the hereafter as well as strengthen their existence as creatures of God.

Furthermore, the supporters of feminist thinking frequently use the concept of benefits of Al-Thufi. However, if examined in more depth, not only does the proposal to reconstruct the rights and obligations of husband and wife put forward by Muslim feminists not meet the criteria of the concept of maslahat as intended by al-Syātibì but it also contradicts the aims of the shariah. According to al- Syātibì, several principles must be fulfilled before using the maslahat method as a legal proposition, namely:

1. The benefit must be in accordance with the Shari'ah's objectives, so that there is no need to contradict the benefit with absolute law.

2. Second, the benefits do indeed make sense.

3. Third, the results of applying maslahat will eliminate the narrowing or shortsightedness that is not desired by the syarā‘. ${ }^{47}$

Of the three criteria determined by al-Syātibī, only the second criterion seems to be accommodated in feminist understanding; while the first and third criteria were not met at all. Because of this, the propositions used by feminists as a basis of argument to support their opinions cannot be accepted because they do not meet the requirements. Thus it is clear that feminist's interpretation put forward in the context of surah al-Nisā verse 34 is nothing more than an shallow understanding of the God verses. Whereas the concept of the rights and obligations of husband and wife is actually very clear and does not require re-interpretation.

\section{Conclusion}

The Muslim Feminist paradigm which reinterprets and reconstructs the role of the husband as the head of the household and the wife as the housewife based on the consideration that now the wives are no

${ }^{47}$ Yusdani, Peranan Kepentingan Umum dalam Reakltualisasi Hukum; Kajian Konsep Hukum Islam Najamuddin al-Thufi, p. 136. 
longer just housewives but also help husbands earn a living, needs to be carefully examined by considering the good and bad aspects it causes to the survival of the family. Because in Islam, marriage is not just a binding agreement between a man and woman to live together in a household but is a sacred bond that has the value of worship to form a sakinah, mawaddah wa rahmah, (harmonious, peaceful and loving household). The consequence of the implementation of the contract is the issuance of the rights and obligations of husband and wife according to their respective roles and positions in accordance with predetermined by Syara'. Strictly speaking, the welfare of the household that is supported by harmonious, peaceful and loving family must take precedence over the consideration of benefit based on equality.

\section{Bibliography}

Aibak, Kutbuddin. Metodologi Pembaharuan Hukum Islam. Yogyakarta: Pustaka Pelajar, 2008.

Anissa, Nova, and Agustin Handayani.'Hubungan Antara Konsep Diri dan Kematangan Emosi dengan Penyesuaian Diri Istri yang Tinggal Bersama Keluarga Suami', Jurnal Psikologi: PITUTUR, 1.1 (2012), 53-64.

Asmawi, Asmawi.'Konseptualisasi Teori Maslahah', SALAM: Jurnal Sosial dan Budaya Syar-i, 1.2 (2014) <https://doi.org/10.15408/sjsbs. v1i2.1548>.

Azizy, A. Qodri. Pemikiran Islam Kontemporer di Indonesia. Yogyakarta: Pustaka Pelajar, 2005

Bunyamin, Mahmudin and Hermanto. Hukum Perkawinan Islam. Bandung: Pustaka Setia, 2017,<//library.unej.ac.id/index.php?p=show_ detail\&id=212396>.

Fakih, Mansour. Analisis Gender \& Transformasi Sosial. Yogyakarta: Insist Press, 2016.

Hasyim, Syafiq. Hal-Hal Yang Tak Terpikitkan Tentang Isu-Isu Perempuan dalam Islam. Bandung: Mizan, 2001.

Haq, Hamka, and al-Syātibi. Aspek Teologis Konsep Maslahah dalam Kitab Al-Muwafaqat. Jakarta: Erlangga, 2007.

Hermanto, Agus.'Islam, Perbedaan dan Kesetaraan Gender', Nizham Journal of Islamic Studies, 5.1 (2017), 31-49. 
,'Rekonstruksi Konsep Hak dan Kewajiban Suami Isteri dalam Perundang-Undangan Perkawinan Indonesia', Justicia Islamica Jurnal Kajian Hukum dan Sosial, 15.1 (2018), 49-86 <https://doi. org/10.21154/justicia.v15i1.1455>.

-'Teori Gender dalam Mewujudkan Kesetaraan: Menggagas Fikih Baru', Ahkam: Jurnal Hukum Islam, 5.2 (2017), 209-232-232 $<$ https://doi.org/10.21274/ahkam.2017.5.2.209-232>.

Imawan, Anang Haris.'Refleksi Pemikiran Hukum Islam: UpayaUpaya Menangkap Simbol Keagamaan', in Anang Haris Himawan, Epistimologi Syara' Mencari Format Baru Fikih Indonesia, I. Jakarta: Pustaka Pelajar, 2000.

Indah, Indah.'Peran-Peran Perempuan dalam Masyarakat', Academica, 5.2 (2014) <http://jurnal.untad.ac.id/jurnal/index.php/academica/ article/view/2247>.

Jughaini, Nu'man al-. Turūq al-Kasyfí̀an Maqūshid al-Syarīah. Yordania: Dār al-Nafá is, 2000.

K, Hamzah.'Revitalisasi Teori Maslahat Mulghah Al-Thūfî dan Relevansinya dalam Pembentukan Perundang-Undangan di Indonesia', AHKAM : Jurnal Ilmu Syariah, 15.1 (2019) <https://doi.org/10.15408/ajis. v15i1.2845>.

Mas'udi, Masdar F. Islam dan Hak-Hak Reproduksi Perempuan: Dialog Fiqih Pemberdayaan. Bandung: Mizan, 1997.

Mu'allim, Amir, and Yusdani. Konfigurasi Pemikiran Hukum Islam. Yogyakarta: UII Press, 2001.

Mukri, Moh. Paradigma Maslahat dalam Pemikiran al-Ghazāli. Yogyakarta: Nawesea Press, 2011.

Mufidah. Isu-Isu Gender Kontemporer dalam Hukum Keluarga. Malang: UIN Maulana Malik Ibrahim, 2010.

Muhammad, Husein, and Faqihuddin Abdul Kodir. Figh Perempuan: Refleksi Kiai atas Wacana Agama dan Gender, Cet. 1. Yogyakarta: LKIS, 2001. Mustafa Ahmad al-Zarqa'. Hukum Islam dan Perubahan Sosial; Setudi Komperatif Delapan Madzhab, Transl. Ade Dede Rahayu. Jakarta: Riora Cipta, 2000.

Muslehuddin, Muhammad. Filsafat Hukum Islam al-Ghazāli; Maslahah Mursalah dan Relevansinya dengan Pembaharuan Hukum Islam. Jakarta: Pustaka Firdaus, 2002. 
, Philosophy of Islamic Law and The Orientalist: A Komperative Studi of Islamic Legal System, Transl. Yudian Wahyudi Asmin. Yogyakarta: Tiara Wacana, t.t.

Pasaribu, Muksana.'Maslahat dan Perkembangannya Sebagai Dasar Penetapan Hukum Islam', JUSTITIA : Jurnal Ilmu Hukum dan Humaniora, 1.04 (2016) <https://doi.org/10.31604/justitia. v1i04.\%p>.

Purwanto, Muhammad Roy.'Kritik Terhadap Konsep Mashlahah Najm Ad-Dīn At-Tūfi', Madania: Jurnal Kajian Keislaman, 19.1 (2015) <https://doi.org/10.29300/madania.v19i1.23>

Qaradhawi, Yusuf al-. Dirasah Fi Figh Maqashid Al-Syariah, Transl. Arif Munandar Riswanto. Jakarta: Pustaka al-Kautsar, 2007.

Syatibi, Abu Ishaq al-. Al-I'tisām, II. Riyadh: al-Haditsah, t.t.

Syarifuddin, Amir. Usul Fikih, 2. Jakarta: Logos Wacana Ilmu, 1999.

Rachman, Alawy. Alawy Rachman, Gelas Kaca dan Kayu Bakar, Pengalaman

Perempuan dalam Pelaksanaan Hak-Hak Keluarga Berencana. Yogyakarta: Pustaka Pelajar, 1998.

Rusdi, Muhammad Ali.'Maslahat Sebagai Metode Ijtihad dan Tujuan Utama Hukum Islam', DIKTUM: Jurnal Syariah dan Hukum, 15.2 (2017), 151-68 <https://doi.org/10.35905/diktum.v15i2.432>

Rosyadi, Imro.'Pemikiran Asy-Syâtibî tentang Maslahah Mursalah', Profetika Jurnal Studi Islam, 14.1 (2016), 78-89-89 <https://doi. org/10.23917/profetika.v14i1.2009>

Suratmaputra, Ahmad Munif. Filsafat Hukum Islam. Jakarta: Pustaka Pirdaus, 2001.

Umar, Nasaruddin, dkk, Bias Jender dalam Pemahaman Islam. Yogyakarta: Gama Media, 2002.

Yusdani. Peranan Kepentingan Umum dalam Reakltualisasi Hukum; Kajian Konsep Hukum Islam Najamuddin al-Thufi. Yogyakarta: UII Press, 2000.

Zahri, Saifuddin. Usūl Figh: Akal Sebagai Sumber Hukum Islam, II. Yogyakarta: Pustaka Pelajar, 2011.

Zuhaili, Wahbah. Usūl Al-Figh al-Islämī, 2. Beirut: Dar al-Fikr, 1987. 